\title{
PENERAPAN SOP PROGRAM PENGAMPUNAN PAJAK TERHADAP UMKM PADA WILAYAH KECAMATAN KRAMAT JATI
}

\author{
Oleh: \\ Deddy Dariansyah \\ Universitas Indraprasta PGRI \\ Email: \\ deddyjogjazz@yahoo.co.id
}

\begin{abstract}
ABSTRAK
Dengan telah diterbitkan Undang Undang No 11 Tahun 2016 dan Peraturan Menteri Keuangan Nomor 118/PMK.03/2016 tentang Pengampunan Pajak, sangat penting dikarenakan masih banyak Wajib Pajak UMKM diwilayah kerja Kantor Pelayanan Pajak Kramat Jati yang belum melaporkan seluruh kekayaan baik berwujud maupun tidak berwujud pada SPT Tahun 2016. Berdasarkan Laporan Kantor Pelayanan Pajak Kramat Jati Wajib Pajak UMKM yang telah mengikuti Program Amnesti Pajak sesuai dengan prosedur sebanyak 1451, diharapkan uang dari tebusan amnesti pajak dapat tercapainya penerimaan Pajak pada Kantor Pelayanan Pajak Kramat Jati pada tahun 2017. Agar dapat tercapainya penerimaan pada Pajak Kantor Pelayanan Pajak Kramat Jati terus meningkatkan kegiatan Ekstensifikasi Pajak, bermanfaat untuk menjaring Wajib Pajak UMKM baru dengan sistem jemput bola agar dapat mengikuti Program Pengampunan Pajak dapat berjalan dengan semestinya, sehingga Tax Ratio dapat meningkat setiap tahunnya.
\end{abstract}

Kata Kunci: Peraturan Pemerintah, Amnesti Pajak. Usaha Mikro Kecil dan Menengah

\section{A. PENDAHULUAN}

Berdasarkan laporan Kementerian Keuangan untuk Anggaran Pendapatan Belanja Negara (APBN) 2016, dari pemerintah menetapkan target penerimaan Pajak non-PPh Migas adalah Rp. 1.546 trilyun, sedangkan pendapatan $\mathrm{PPh}$ Minyak dan Gas Bumi sebesar Rp. 41.4 Triliun. Dengan perluasan dasar perhitungan tersebut, pemerintah mengusulkan rasio penerimaan Pajak (Tax Ratio) dalam Rancangan Anggaran Pendapatan dan Belanja Negara Perubahan (APBN) 2016 sebesar 13\% dari Produk Domestik Bruto (PDB). Dengan semakin meningkatnya target penerimaan negara dari sektor pajak pada struktur APBN dari tahun ke tahun, yang besarnya rasio penerimaan sektor pajak terhadap total penerimaan dalam negeri berkisar 78\% . untuk di tahun 2016 ini saja, total target penerimaan sektor pajak pada Anggaran Pendapatan Belanja Negara (APBN ) sebesar 1.546 Trilyun. Berikut ini Tabel Target Penerimaan Pajak selama 5 tahun dari Tahun 2012 sampai dengan 2016 dari Direktorat Jendral Pajak berdasarkan APBN adalah sebagai berikut: 


\begin{tabular}{|c|c|c|}
\hline No & Tahun Penerimaan Pajak & Jumlah Target Penerimaan \\
\hline 1 & 2012 & Rp 980 triliun \\
2 & 2013 & Rp 1.072 triliun \\
3 & 2014 & Rp 1.110 triliun \\
4 & 2015 & Rp 1.294 trilyun \\
5 & 2016 & Rp 1.546 trilyun \\
\hline \multicolumn{2}{|c}{ Sumber Direktorat Jendral Pajak }
\end{tabular}

Dari tabel di atas terlihat sangat jelas bahwa setiap tahunnya target penerimaan Pajak meningkat jumlahnya, berdasarkan Anggaran Pendapatan Belanja Negara (APBN). Hal ini diperlukan langkah-langkah strategis dan tepat oleh Direktorat Jendral Pajak sebagai institusi pengumpul penerimaan negara di Indonesia, agar rencana penerimaan pajak dapat tercapai, dari Pihak Direktorat Jendral Pajak menjalankan Program Ekstensifikasi dan Intensikasi, salah satu diantaranya Program Pengampunan Pajak (Tax Amnesty). Berdasarkan data dashboard Direktorat Jenderal Pajak, pada Oktober 2016 pada nilai pernyataan harta berdasarkan Surat Pernyataan Harta $(\mathrm{SPH})$ telah mencapai Rp 3.811 triliun. Jika dirinci, sebanyak $\mathrm{Rp} 2.690$ triliunmerupakan deklarasi dalam negeri. kemudian, sebanyak Rp 979 triliun berupa dana deklarasi luar negeri dan sisanya Rp 142 triliun merupakan dana repatriasi. Salah satu tujuan Program Pengampunan Pajak (Tax Amesty) adalah target pemerintah khususnya Direktorat Jendral Pajak agar bisa menarik sekitar Rp1.000 Triliun sampai dengan Rp 4.000 triliun dana yang terparkir di luar negeri, diharapkan dapat tercapainya target penerimaan Pajak setiap tahunnya.

Dalam praktiknya, bila dilakukan penelitian secara langsung kepada subjek pajak, bahwa melaksanakan Program Pengampunan Pajak (Tax Amnesty) saat ini yang sederhana, mudah dilaksanakan dengan tarif yang sangat rendah merupakan salah satu yang diinginkan oleh masyarakat. Kondisi tersebut tidak terkecuali bagi kalangan pelaku usaha yang tergolong dalam Usaha Mikro Kecil dan Menengah dengan berbagai keterbatasan yang ada ditengah kegiatan usaha pada saat ini, diharapkan dapat diperoleh yaitu berupa keuntungan yang telah diharapkan, sehingga dapat menjaga dan mendorong kelangsungan Usaha Mikro Kecil dan Menengah yang terus berlanjut, atas dasar pemikiran tersebut penulis tertarik untuk meneliti Penerapan Standar Operasional Prosedur Program Pengampunan Pajak terhadap Usaha Mikro Kecil dan Menengah (UMKM) Pada Wilayah Kecamatan Kramat Jati. Berdasarkan Laporan Kantor Pelayanan Pajak Kramat Jati Pengusaha UMKM yang mengikuti Program Amnesti Pajak sebanyak 1451 Wajib Pajak UMKM, diharapakan sebelum akhir Program Amnesti Pajak akhir Maret 2017 lebih banyak lagi Wajib Pajak yang mengikuti Program Amnesti Pajak sehingga dapat tercapainya penerimaan Pajak pada Kantor Pelayanan Pajak Kramat Jati. Sebelum membahas lebih lanjut penerapan dari Program Amnesti Pajak ini, berikut ini beberapa pengertian yang perlu dikemukakan dalam memahami dan melaksanakan Program Pengampunan Pajak sebagaimana berikut ini. 


\section{B. TINJAUAN PUSTAKA}

Pajak berasal dari (dari bahasaLatintaxo; "rate") adalah iuran rakyat kepada negara berdasarkan undang-undang, sehingga dapat dipaksakan, dengan tidak mendapat balas jasa secara langsung. Sedangkan definisi Pajak menurut Undang Undang Nomor 16 tahun 2009 tentang perubahan tentang Ketentuan Umum dan Tata cara Perpajakan, Pajak adalah kontribusi wajib kepada negara yang terutang oleh pribadi atau badan yang bersifat memaksa berdasarkan Undang Undang, dengan tidak mendapatkan imbalan secara langsung dan digunakan untuk keperluan negara bagi sebesar besarnya untuk kemakmuran rakyat. Sedangkan definisi Pajak menurut kutipan Jurnal Pajak Tryana AM Tiradaa Volume 3 (2013) Waluyo (2011:4) menyatakan pajak adalah kewajiban yang melekat kepada setiap warga yang memenuhi syarat yang telah ditetapkan oleh Undang-Undang agar membayar sejumlah uang ke Kas Negara yang bersifat memaksa, dan tidak mendapatkan imbalan secara langsung. Sedangkan Wajib Pajak dibagi menjadi dua menurut kutipan Jurnal Pajak Winda Kurnia Fikriningrum (2012), adalah wajib pajak merupakan orang pribadi atau badan, meliputi pembayar pajak, pemotong pajak, dan pemungut pajak yang mempunyai hak dan kewajiban perpajakan sesuai dengan ketentuan peraturan perundang-undangan perpajakan.

Berdasarkan Undang-Undang Nomor 11 Tahun 2016, Pengampunan Amnesti Pajak adalah penghapusan pajak yang seharusnya terutang, tidak dikenakan sanksi administrasi perpajakan dan sanksi pidana di bidang perpajakan, dengan cara mengungkap harta dan membayar Uang Tebusan sebagaimana diatur dalam Undang-Undang ini. Berdasarkan Undang Undang Nomor 11 Tahun 2016, selain memberikan pengampunan untuk sanksi administrasi, tax amnesty juga dimaksudkan untuk menghapuskan sanksi pidana, serta pengampunan pajak (tax amnesty) juga dapat diberikan kepada pelaporan sukarela data kekayaan wajib pajak yang belum dilaporkan pada masa sebelumnya tanpa harus membayar pajak yang mungkin belum dibayarkan. Namun demikian Tax Amnesty ini ditujukan tidak hanya kepada Warga Negara Indonesia yang memiliki harta atau aset di luar negeri saja. Bagi Wajib Pajak dalam negeri khususnya bagi Wajib Pajak Usaha Mikro Kecil dan Menengah (UMKM) berhak untuk mengikuti Program Pengampunan Amnesti Pajak ini apabila masih ada harta atau aset yang belum di laporkan dalam SPT Tahunannya sehingga tetap terdapat unsur keadilan. Sedangkan menurut kutipan Jurnal Pajak Ngadiman dan Daniel Huslim (2015) menyatakan Tax amnesty adalah suatu kesempatan waktu yang terbatas pada kelompok pembayar pajak tertentu untuk membayar sejumlah tertentu dan dalam waktu tertentu berupa pengampunan kewajiban pajak (termasuk bunga dan denda) yang berkaitan dengan masa pajak sebelumnya atau periode tertentu tanpa takut hukuman pidana.

1. Subjek dan Objek Program Amnesti Pajak

Dalam pasal 3 undang undang Amnesty Pajak, Subjek Amnesti pajak adalah setiap Wajib Pajak berhak untuk mendapatkan pengampunan pajak melalui pengungapan harta yang dimilikinya dalam Surat Pernyataan kecuali Wajib Pajak yang sedang: 
a. Dilakukan penyidikan dan berkas penyidikannya telah dinyatakan lengkap oleh Kejaksaan Republik Indonesia

b. Dalam proses peradilan pengadilan Republik Indonesia

c. Menjalani hukum pidana, atas Tindak Pidana di bidang Perpajakan

Apabila belum terdaftar sebagai Wajib Pajak (belum Ber NPWP) agar mendaftarkan diri untuk mendapatkan NPWP dulu ke Kantor Pelayanan Pajak dimana Wajib Pajak tempat tinggal atau domisili. Sedangkan Objek Amnesti Pajak adalah meliputi pengampunan atas kewajiban perpajakan sampai dengan akhir tahun pajak terakhir, yang belum atau belum sepenuhnya diselesaikan oleh Wajib Pajak terdiri atas:

a) Pajak Penghasilan

b) Pajak Pertambahan Nilai dan Pajak Penjualan atas Barang Mewah

2. Tujuan Program Amnesti Pajak berdasarkan Undang-undang nomor 11 Tahun 2016 adalah sebagai berikut:

a) Mempercepat pertumbuhan dan restrukturisasi ekonomi melalui pengalihan Harta, yang antara lain akan berdampak terhadap peningkatan likuiditas domestik, perbaikan nilai tukar Rupiah, penurunan suku bunga, dan peningkatan investasi;

b) Mendorong reformasi perpajakan menuju sistem perpajakan yang lebih berkeadilan serta perluasan basis data perpajakan yang lebih valid, komprehensif, dan terintegrasi; dan

c) Meningkatkan penerimaan pajak, yang antara lain akan digunakan untuk pembiayaan pembangunan.

3. Manfaat Program Amnesti Pajak

a) Peningkatan Tax Ratio melalui pencapaian target penerimaan pajak pada setiap tahunnya

b) Peningkatan investasi dan likuiditas domestik, serta perbaikan nilai tukar rupiah, dan penurunan suku bunga.

c) Perluasan basis data perpajakan yang lebih valid komprehensif dan terintegrasi.

4. Program Amnesti Pajak (Tax Amnesty) tetap berpegang teguh berdasarkan asas :

a) Kepastian hukum, yaitu pelaksanaan pengampunan pajak harus dapat mewujudkan ketertiban dalam masyarakat melalui kepastian hukum.

b) Keadilan, yaitu pengampunan pajak menjunjung tinggi keseimbangan hak dan kewajiban dari setiap pihak yang telibat.

c) Kemanfaatan, yaitu seluruh pengaturan kebijakan pengampunan pajak bermanfaat bagi kepentingan negara,bangsa dan masyarakat, khususnya dalam memajukan kesejahteraan umum.

d) Kepentingan nasional, yaitu pelaksanaan pengampunan pajak kepentingan bangsa,negara dan masyarakat di atas kepentingan lainnya.

5. Dasar Hukum Program Amnesti Pajak 
Dasar Hukum perhitungan Program amnesti pajak adalah Pasal 4 Undang Undang No 11 Tahun 2016 dan Pasal 10 Peraturan Menteri Keuangan Nomor 118/PMK.03/2016 tentang Pelaksanaan UU No 11 Tahun 2016 Tentang Pengampunan Pajak serta (kutipan Jurnal pajak 4). Untuk menghitung besarnya uang tebusan yang harus dibayar sehingga wajib pajak memperoleh pengampunan pajak, fasilitas yang diberikan oleh Pemerintah kepada Wajib Pajak meliputi penghapusan pajak yang seharusnya terutang, penghapusan sanksi administrasi perpajakan, serta penghapusan sanksi pidana di bidang perpajakan atas harta yang diperoleh pada tahun 2015 dan sebelumnya yang belum dilaporkan dalam SPT.

6. Tarif Program Amnesti Pajak

Sebagaimana yang tertuang dalam pasal 4 UU No 11 Tahun 2016, Hartaadalah akumulasi tambahan kemampuan ekonomis berupa seluruh kekayaan, baik berwujud maupun tidak berwujud, baik bergerak maupun tidak bergerak baik yang digunakan untuk usaha maupun bukan untuk usaha, yang berada didalam dan/atau diluar wilayah Negara Kesatuan Republik Indonesia. Sedangkan Utang adalah jumlah pokok utang yang belum dibayar yang berkaitan langsung dengan perolehan Harta. Tarif uang tebusan atau harta yang berada di dalam wilayah Negara Kesatuan Republik Indonesia atau Harta yang berada di luar wilayah Negara Kesatuan Republik Indonesia yang dialihkan ke dalam wilayah Negara Kesatuan Republik Indonesia dan diinvestasikan dalam jangka waktu paling singkat 3 tahun terhitung sejak dialihkan, adalah sebesar:

a) $2 \%$ (dua persen) untuk periode penyampaian Surat Pernyataan pada bulan pertama sampai dengan akhir bulan ketiga, pada tanggal $18 \mathrm{Juli}$ s.d 30 September 2016

b) $3 \%$ (tiga persen) untuk periode penyampaian Surat Pernyataan pada 1 Oktober 2016 sampai dengan 31 Desember 2016

c) $5 \%$ (lima persen) untuk periode penyampaian surat pernyataan terhitung sejak tangggal 1 Januari 2017 sampai dengan tanggal 31 Maret 2017.

Tarif uang tebusan bagi Wajib Pajak UMKM yang peredaran usahanya sampai dengan pada tahun pajak terakhir adalah sebesar :

a) $\quad 0,5 \%$ (nol koma lima persen) bagi wajib pajak yang mengungkapkan nilai harta sampai dengan $\mathrm{Rp}$ 10.000.000.000,00 (sepuluh miliar rupiah) dalam Surat Pernyataan; atau

b) $2 \%$ (dua persen) bagi wajib pajak yang mengungkapkan nilai harta lebih dari $\mathrm{Rp}$ 10.000.000.000,00 (sepuluh miliar) dalam Surat Pernyataan.

Selain landasan teori diatas tentang Program Amnesti Pajak, dari pihak Direktorat Jendral Pajak juga memberikan penjelasan simbol makna tentang Program Amnesti Pajak yaitu : Ungkap, Tebus, Lega

Ungkap adalah sebuah pernyataan dari Wajib Pajak untuk bersedia melaporkan seluruh kekayaan, baik berwujud maupun tidak berwujud, baik bergerak maupun tidak bergerak, baik yang digunakan untuk usaha maupun bukan untuk usaha, yang berada didalam dan/atau diluar negeri, yang belum dilaporkan 
salam SPT Tahunan PPh terakhir. Belum dilaporkannya kekayaan tersebut bisa dikarenakan kelalaian atau keadaan diluar kekuasaan yang dialami Wajib Pajak, sehingga kolom Harta dan Utang dalam SPT Tahunan PPh belum diisi dengan benar, lengkap dan jelas.

Tebus adalah pembayaran sejumlah uang ke kas Negara untuk mendapatkan Amnesti Pajak, berupa pelepasan hak Negara untuk menagih pajak yang seharusnya terutang dari pengungkapan kekayaan yang dilakukan oleh wajib pajak kepada Direktorat Jendral Pajak. Uang Tebusan atas Amnesti Pajak dihitung dengan cara mengalihkan tarif Uang Tebusan dengan Nilai Harta Bersih yang telah diiungkapkan oleh wajib pajak.

Lega adalah sebuah perasaan yang nantinya akan menaungi wajib pajak manakala mereka telah memanfaatkan pengampnan pajak. Dengan diterimanya Pengampunan Pajak, Wajib Pajak akan mendapatkan penghapusan atas pajak yang seharusnya terutang sanksi administrasi perpajakan, dan sanksi pidana di bidang perpajakan untuk kewajiban perpajakan sebelum 31 Desember 2015.

Menurut Kutipan Jurnal UMKM Hasan (2013) pengertian Usaha Mikro Kecil dan Menengah berdasarkan Undang Undang No 20 Tahun 2008 adalah sebagai berikut:

Usaha Mikro adalah usaha produktif milik orang perorangan dan/atau badan usaha perorangan yang memenuhi kriteria Usaha Mikro sebagaimana diatur dalam Undang-Undang ini.

Usaha Kecil adalah usaha ekonomi produktif yang berdiri sendiri, yang dilakukan oleh orang perorangan atau badan usaha yang bukan merupakan anak perusahaan atau bukan cabang perusahaan yang dimiliki, dikuasai, atau menjadi bagian baik langsung maupun tidak langsung dari usaha menengah atau usaha besar yang memenuhi kriteria Usaha Kecil sebagaimana dimaksud dalam UndangUndang ini.

Usaha Menengah adalah usaha ekonomi produktif yang berdiri sendiri, yang dilakukan oleh orang perseorangan atau badan usaha yang bukan merupakan anak perusahaan atau cabang perusahaan yang dimiliki, dikuasai, atau menjadi bagian baik langsung maupun tidak langsung dengan Usaha Kecil atau usaha besar dengan jumlah kekayaan bersih atau hasil penjualan tahunan sebagaimana diatur dalam Undang-Undang ini.

Menurut Peraturan Menteri Keuangan (PMK) Nomor : 197/PMK.03/2013 pengertian Pengusaha Kecil adalah Pengusaha yang selama satu tahun buku melakukan penyerahan Barang Kena Pajak dan/atau Jasa Kena Pajak dengan jumlah peredaran bruto dan/atau penerimaan bruto tidak lebih dari Rp 4.800.000.000,00 (empat milyar delapan ratus juta rupiah).

Sedangkan menurut Undang Undang No 20 tahun 2008 tentang usaha mikro kecil dan menengah, menyatakan paahwa pengertian Usaha Mikro adalah usaha produktif milik orang perorangan dan/atau badan usaha perorangan yang memenuhi kriteria Usaha Mikro sebagaimana diatur dalam Undang-Undang ini. Selanjutnya pengertian Usaha Kecil adalah usaha ekonomi produktif yang berdiri sendiri, yang dilakukan oleh orang perorangan atau badan usaha yang bukan merupakan anak perusahaan atau bukan cabang perusahaan yang dimiliki, dikuasai, atau menjadi bagian baik langsung maupun tidak langsung dari Usaha 
Menengah atau Usaha Besar yang memenuhi kriteria Usaha Kecil sebagaimana dimaksud dalam Undang-Undang ini. dan terakhir pengertianUsaha Menengah adalah usaha ekonomi produktif yang berdiri sendiri, yang dilakukan oleh orang perorangan atau badan usaha yang bukan merupakan anak perusahaan atau cabang perusahaan yang dimiliki, dikuasai, atau menjadi bagian baik langsung maupun tidak langsung dengan Usaha Kecil atau Usaha Besar dengan jumlah kekayaan bersih atau hasil penjualan tahunan sebagaimana diatur dalam Undang- Undang ini. Didalam Undang Undang UMKM No 20 Tahun 2008 dan kutipan (Mangonting, 2017) menyatakan " isi kutipan" Jurnal UMKM Usaha Mikro Usaha Kecil dan Menengah secara tegas juga memberikan kriteria dari usaha untuk dikategorikan sebagai berikut:

(1) Kriteria Usaha Mikro adalah sebagai berikut:

a. memiliki kekayaan bersih paling banyak Rp50.000.000,00 (lima puluh juta rupiah) tidak termasuk tanah dan bangunan tempat usaha; atau

b. memiliki hasil penjualan tahunan paling banyak Rp300.000.000,00 (tiga ratus juta rupiah).

(2) Kriteria Usaha Kecil adalah sebagai berikut:

a. memiliki kekayaan bersih lebih dari Rp50.000.000,00 (lima puluh juta rupiah) sampai dengan paling banyak Rp500.000.000,00 (lima ratus juta rupiah) tidak termasuk tanah dan bangunan tempat usaha; atau

b. memiliki hasil penjualan tahunan lebih dari Rp300.000.000,00 (tiga ratus juta rupiah)

c. sampai dengan paling banyak Rp2.500.000.000,00 (dua milyar lima ratus juta rupiah).

(3) Kriteria Usaha Menengah adalah sebagai berikut:

a. memiliki kekayaan bersih lebih dari Rp500.000.000,00 (lima ratus juta rupiah) sampai dengan paling banyak Rp10.000.000.000,00 (sepuluh milyar rupiah) tidak termasuk tanah dan bangunan tempat usaha; atau

b. memiliki hasil penjualan tahunan lebih dari Rp2.500.000.000,00 (dua milyar lima ratus juta rupiah) sampai dengan paling banyak Rp50.000.000.000,00 (lima puluh milyar rupiah).

\section{METODE PENELITIAN}

Metode penelitian yang digunakan dalam Penelitian ini adalah menganalisa Penerapan Standar Operasional Prosedur Program Amnesti Pajak sudah sesuai dengan Pasal 4 Undang Undang No 11 Tahun 2016 dan Pasal 10 Peraturan Menteri Keuangan Nomor 118 / PMK.03/2016 yang ada di wilayah kerja Kantor Pelayanan Pajak Kecamatan Kramat Jati. 


\section{HASIL DAN PEMBAHASAN}

Sebelum menjelaskan lebih lanjut bagaimana mekanisme Standar Operasional Prosedur Program Amnesti Pajak (Tax Amnesty) bagi Wajib Pajak UMKM di Wilayah Kecamatan Kramat Jati dapat mengikuti Program ini? Sebenarnya cara yang perlu dilakukan tidak terlalu sulit, hampir sama dengan yang ada di dalam negeri, sejalan dengan semboyan Program Amnesti Pajak yaitu: Ungkap, Tebus dan Lega sebagaimana digencarkan diberitakan selama ini. Berikut ini mekanisme Prosedur yang perlu disiapkan Wajib Pajak UMKM, agar nantinya pengajuan permohonan Amnesti Pajak Wajib Pajak UMKM ke Kantor Pelayanan Pajak Kramat Jati tidak ditolak oleh tim penerima berkas (helpdesk) dan tim peneliti berkas, sebagai berikut.

1. Wajib Pajak UMKM terlebih dahulu Membuat laporan Daftar Harta yang dimiliki pada Tahun Pajak awal Januari sampai dengan akhir Desember, yaitu:

a. Wajib Pajak UMKM dengan membuat Daftar Hartakeseluruhan, harta yang dimiliki atau yang sudah pernah atau belum di laporkan pada SPT Tahunan PPh Badan / Orang Pribadi

b. Setelah itu Wajib Pajak UMKM membuat daftar harta tambahan yang dipisahkan berdasarkan lokasi dan perlakuan:Harta tambahan dalam negeri, Harta Tambahan di Luar Negeri yang hendak di repatriasi, Harta Tambahan di Luar Negeri yang tidak akan di repatriasi.

2. Setelah selesai Wajib Pajak UMKM membuat laporan Daftar Harta yang dimiliki pada Tahun Pajak Awal Januari sampai dengan Akhir Desember, kemudian membuat Laporan Daftar Hutang yang dimiliki keseluruhan hutang, baik yang sudah laporkan atau belum dilaporkan pada SPT Tahunan $\mathrm{PPh}$ Badan / Orang Pribadi. Daftar Hutang Tambahan yang dipisahkan berdasarkan lokasi dan perlakuan :

a. Hutang tambahan dalam negeri

b. Hutang Tambahan di Luar Negeri terkait harta yang hendak di repatriasi

c. Hutang Tambahan di Luar Negeri terkait harta yang tidak akan di repatriasi

3. Hitung Jumlah Uang Tebusan Amnesti Pajak

Setelah daftar harta dan daftar hutang selesai dibuat, maka langkah selanjutnya sebelum Wajib Pajak UMKM adalah menghitung jumlah uang tebusan yang harus dibayar terkait dengan jumlah tambahan harta dan utang, Berikut ini mekanisme perhitungan jumlah Uang tebus Amnesti Pajak.

\section{Mekanisme Perhitungan Pengampunan Pajak}

Menurut Kutipan Jurnal D Erica (2017) menyatakan Sesuai dengan Pasal 4 Undang Undang No 11 Tahun 2016 dan Pasal 10 Peraturan Menteri Keuangan Nomor 118 / PMK.03/2016 dan Kutipan Jurnal Pajak bahwa

Seorang Wajib Pajak UMKM memiliki harta yang berada dalam Surat Pemberitahuan Tahunan Pajak Penghasilan Tahun Pajak 2015 (SPT Pajak Penghasilan terakhir), Wajib Pajak melaporkan: 

a. Nilai harta Rp 3.000.000.000,-
b. Nilai hutang Rp 1.000.000.000,-
c. Nilai harta bersih Rp 2.000.000.000,-

Setelah akhir September Wajib Pajak UMKM melaporkan kembali dengan mengikuti Progam Amnesti Pajak, dalam surat pernyataan yang disampaikan pada bulan pertama sampai dengan akhir bulan ketiga (akhir September 2016) diketahui adalah sebagai berikut:

a. Nilai harta $\operatorname{Rp} 4.000 .000 .000,-$

b. Nilai hutang Rp 1.000.000.000,-

c. Nilai harta bersih Rp 3.000.000.000,-

Dengan demikian dasar perhitungan pengenaan uang tebusan bagi Wajib Pajak UMKM adalah: Rp 3.000.000.000,- $-\mathrm{Rp} 2.000 .000 .000,-=\mathrm{Rp}$ 1.000.000.000,-

Tarif yang dikenakan untuk uang tebusan Amnesti Pajak dikenakan 0,5\% sesuai dengan Undang Undang Amnesti pajak, apabila bagi wajib pajak UMKM yang mengungkapkan nilai harta sampai dengan Rp 10.000.000.000,00 (sepuluh miliar rupiah) dalam Surat Pernyataan.

$$
\text { Rp 1.000.000.000 x 0,5\%= Rp 5.000.000,- }
$$

4. Mengisi Formulir Amnesti Pajak

Setelah Wajib Pajak UMKM selesai menghitung besaran uang tebusan dan telah memiliki bayangan nominalnya, maka langkah selanjutnya adalah mengisi lampiran lembar "surat pernyataan harta untuk pengampunan pajak", ingat untuk mengisi laporan pajak apapun itu selalu dimulai dengan mengisi lampiran. Wajib Pajak UMKM bisa mendapatkan formulir Amnesti Pajak melalui internet dapat diunduh dengan mengunjungi website Direktorat Jendral Pajak www. Pajak. go.id/ amesti pajak atau Wajib Pajak bisa mendatangi Kantor Pelayanan Pajak terdekat untuk meminta Formulir Amnesti Pajak. Pertama tama Wajib Pajak UMKM dapat membuka aplikasi Amesti Pajak terintegrasi dalam bentuk excel telah unduh, bagian pertama yang harus anda isi adalah sheet isian data sebagai berikut:
a) SURAT PERNYATAAN : Bila baru pertama kali menyampaikan maka isi 1
b) NPWP : Isikan NPWP Wajib Pajak tanpa tanda baca cukup nomer saja
c) NAMA : Isikan Nama Wajib Pajak
d) NIK KTP : Isikan NIK bila wajib pajak adalah Orang Pribadi, kosongkan bila wajib pajak badan
e) NOMOR PASSPORT :Isikan bila wajib pajak adalah Orang Pribadi jika memliki Passport, kosongkan bila wajib pajak badan
f) ALAMAT DI INDONESIA : Isi dengan alamat tempat tinggal / kantor di Indonesia 
g) ALAMAT DI LUAR NEGERI : Isikan dengan alamat tempat tinggal / kantor di luar negeri

h) BIDANG USAHA : Isikan bidang usaha sesuai dengan apa yang tercantum dalam surat keterangan terdaftar pada saat pertama kali anda mendaftarkan diri untuk mendapatkan NPWP dulu

i) TELEPON RUMAH : Isi dengan Nomer telepon rumah bila ada, bila tidak ada cukup dikosongkan

j) NOMOR HANDPHONE : Masa ndak punya HP :D

k) ALAMAT EMAIL : Isikan alamat email anda

1) UMKM YA / TIDAK : Pilih Pada dropdown apakah peredaran usaha anda setahun tidak melebihi 4.800.000.000 bila dibawah maka pilih ya, dan bila diatas maka pilih tidak

m) KLU (KLASIFIKASI LAPANGAN USAHA) : KLU anda dapat anda lihat di lembar surat keterangan terdaftar sama halnya dengan bidang usaha

n) PEMBUKUAN : Pilih apakah anda menggunakan pembukuan atau tidak

o) PERIODE PEMBUKUAN : Periode pembukuan normalnya adalah dimuai dari bulan januari sampai bulan desember jadi isikan 0112 artinya bulan 01 sampai bulan 12

p) DI AUDIT ATAU TIDAK : Bila anda diaudit oleh akuntan publik maka pilih ya dan bila tidak maka pilih tidak

q) PAKAI KONSULTAN ATAU TIDAK : Silahkan pilih pada dropdown menu apakah anda menggunakan konsultan publik atau tidak

r) NAMA KONSULTAN : Kosongkan bila anda tidak menggunakan konsultan dan membuat sendiri laporan perpajakan anda

s) TARIF UNTUK HARTA YANG DIALIHKAN KE DN : Silahkan isikan tarif anda, baca di halaman TARIF bila anda tidak mengetahui

t) TARIF UNTUK HARTA TIDAK DIBAWA KE DN : Kosongkan bila anda tidak memiliki harta diluar negeri, baca di halamanTARIF bila anda tidak mengetahui

u) JENIS WAJIB PAJAK : Pilih apakah anda wajib pajak orang pribadi atau anda wajib pajak badan

v) NAMA PENANDATANGAN : Isikan direktur bila badan dan isi sesuai nama wajib pajak bila anda adalah wajib pajak orang pribadi

w) NPWP Isikan NPWP direktur bila badan dan isi sesuai NPWP wajib pajak bila anda adalah wajib pajak orang pribadi

x) ALAMAT : Isikan alamat orang yang menandatangani

y) KOTA SURAT DIBUAT : Isi kota tempat terdaftar sesuai dengan kartu NPWP

z) NAMA KANTOR PELAYANAN PAJAK : Isikan Nama Kantor tempat anda terdaftar

5. Isi Surat Pernyataan Harta Untuk Pengampunan Pajak 
Wajib Pajak UKM harus mengisi semua isi surat pernyataan harta untuk pengampunan pajak yang tertera didalam surat pernyataan tersebut

6. Cetak Surat Pernyataan Harta Untuk Pengampunan Pajak

Apabila Wajib Pajak UMKM telah mengisi semua formulir Amnesti Pajak dengan benar dan lengkap maka saatnya untuk mencetak, jangan lupa "surat pernyataan harta untuk pengampunan pajak" dicetak menggunakan kertas folio A4.

7. Siapkan Data Pendukung Surat Pernyataan Harta Untuk Pengampunan Pajak

Untuk melengkapi surat pernyataan harta diperlukan data pendukung, data pendukung yang dimaksud adalah data yang mendukung pernyataan Wajib Pajak UMKM yang telah tertera pada surat pernyataan harta. Contoh nyata surat pendukung adalah rekening hutang di bank, bukti hutang di FIF / BAF dan bukti hutang lainnya. Untuk harta Wajib Pajak tidak perlu membawa buktinya karena pengakuan tanpa bukti sudah cukup untuk harta.

8. Konsultasikan perhitungan pengampunan Pajak dengan petugas AR / Account Representative

Bila semua telah siap maka saatnya Wajib Pajak berkonsultasi dengan petugas Account Representatif tentang kebenaran penghitungan yang telah anda buat, bisa mendatangi ke Kantor Pelayanan Pajak terdekat atau bisa melalui telepon, email, atau whatsapp, bila anda tidak memiliki nomor Petugas Account Representatif maka gunakan tips ini untuk mencari kantor pajak yang telah disediakan untuk anda :

1) Hubungi petugas telkom (kode kota) 108 contoh 0356-108

2) Tanyakan kepada petugas telkom berapa nomer kantor pajak kota anda

3) Hubungi Kantor Pajak kemudian minta disambungkan ke HELP DESK

4) Sebutkan NPWP Wajib Pajak UMKM dan tanya siapa petugas AR / minta dihubungkan dengan petugas AR / cukup minta nomer telepon petugas AR anda kepada petugashelp desk. Wajib Pajak UMKM dapat berkonsultasi tentang perhitungan uang tebusan yang di hitung apakah sudah benar atau belum.

9. Membayar Uang Tebusan Amnesti Pajak

Apabila Wajib Pajak telah berkonsultasi dengan petugas Account Representatif dan disimpulkan tidak ada masalah dengan perhitungan Amnesti pajak, maka Wajib Pajak dapat langsung membayar uang tebusan amnesti pajak di Bank Persepsi atau Bank yang telah bekerja sama dengan pihak Direktorat Jendral Pajak, baik Bank BUMN, BUMD, Swasta dalam negeri, Kantor Pos, atau bisa menggunakan Anjungan Tunai Mandiri (ATM) bank terdekat, setelah membayar maka Wajib Pajak dapat membawa bukti print dari ATM tersebut ke Kantor Pelayanan Pajak. 
10. Bawa Berkas Permohonan Pengampunan Amnesti Pajak ke Kantor Pelayanan Pajak

Setelah Wajib Pajak UMKM membayar uang tebusan pada Bank, Kantor Pos atau ATM, selanjutnya Wajib Pajak UMKM dapat menyampaikan surat pernyatan harta untuk Program Pengampunan Pajak beserta lampirannya pada Kantor Pajak Kramat Jati, dari data yang dilaporkan wajib data yang asli dan harus sesuai, setelah diperiksa petugas kantor pajak kemudian Wajib Pajak UMKM akan mendapatkan surat keterangan dalam waktu kurang lebih 10 hari setelah proses tersebut berlangsung.

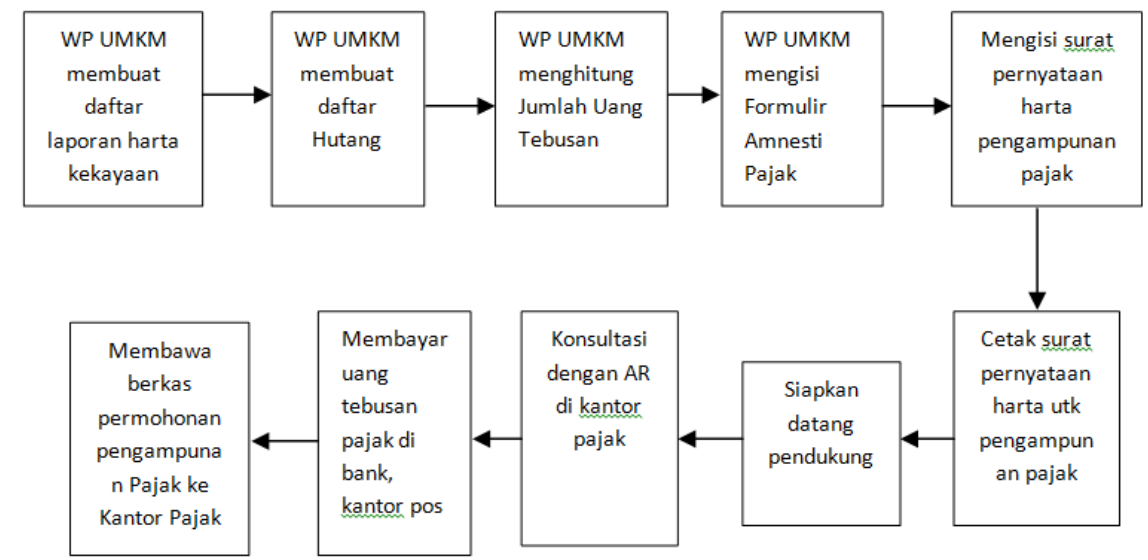

Bagan Prosedur Program Pengampunan Pajak UMKM

Dari hasil penelitian selama Tiga ( bulan ) bulan September sampai dengan Desember 2016 di Kantor Pelayanan Pajak Kramat Jati, sejumlah 1451 Wajib Pajak UMKM telah mengikuti Prosedur Program Amnesti Pajak berdasarkan Undang Undang No 11 Tahun 2016 dan Pasal 10 Peraturan Menteri Keuangan Nomor 118/PMK.03/2016

\section{E. SIMPULAN dan SARAN}

Dengan telah diterbitkan Undang Undang No 11 Tahun 2016 dan Peraturan Menteri Keuangan Nomor 118/PMK.03/2016 tentang Pengampunan Pajak, sangat penting dikarenakan masih banyak Wajib Pajak khususnya UMKM belum melaporkan seluruh kekayaan, baik berwujud maupun tidak berwujud, baik bergerak maupun tidak bergerak, baik yang digunakan untuk usaha maupun bukan untuk usaha, yang berada didalam dan /atau diluar negeri didalam SPT Tahunan Pajak Penghasilan terakhir. Belum dilaporkannya kekayaan tersebut bisa dikarenakan kelalaian atau keadaan diluar kekuasaan yang dialami Wajib Pajak, sehingga kolom Harta dan Utang dalam SPT Tahunan PPh belum diisi dengan benar, lengkap dan jelas.

Pertimbangan Pemerintah penerapan pengenaan pengampunan pajak bagi Wajib Pajak UMKM, Tarif uang tebusan pengampunan pajak bagi Wajib Pajak UMKM yang peredaran usahanya sebesar : 0,5\% (nol koma lima persen) bagi 
wajib pajak yang mengungkapkan nilai harta sampai dengan $\mathrm{Rp}$ 10.000.000.000,00 (sepuluh miliar rupiah) dalam Surat Pernyataan; atau2\% (dua persen) bagi wajib pajak yang mengungkapkan nilai harta lebih dari $\mathrm{Rp}$ 10.000.000.000,00 (sepuluh miliar) dalam Surat Pernyataan. didasari atas rasa keadilan yang ingin diberikan kepada Wajib Pajak UMKM. Peran UMKM dirasakan sangat penting bagi negara Republik Indonesia untuk menggerakan perekonomian sektor riil, dan pemasukan pendapatan negara dari sektor Pajak khususnya.

Dari data Kantor Pelayanan Pajak Pratama Kramat Jati Tahun 2016, jumlah Wajib Pajak UMKM pada Kantor Pelayanan Pajak Kramat Jati, sejumlah 1451, telah mengikuti Prosedur Program Amnesti Pajak berdasarkan Undang Undang No 11 Tahun 2016 dan Pasal 10 Peraturan Menteri Keuangan Nomor 118/PMK.03/2016. Dari data tersebut merupakan sangat bagus untuk potensi penerimaan pajak pada Kantor Pelayanan Pajak Pratama Kramat jati dalam menjalankan Program Pengampunan Pajak, selain itu Kantor Pelayanan Pajak Kramat Jati terus menjalankan Ekstensifikasi Pajak untuk menjaring Wajib Pajak UMKM baru yang belum mengikuti Program Pengampunan Pajak sebagai penerimaan pajak pada Wilayah kerja Kecamatan Kramat Jati. Berbagai macam cara menjalankan program Ekstensifikasi Pajak dalam menjaring Wajib Pajak UMKM yang ada di wilayah Kantor Pelayanan Pajak Kramat Jati antara lain:

1. Mapping Survey terhadap pelaku usaha UMKM di wilayah Kecamatan Kramat Jati

2. Melaksanakan sosialisasi dan memberikan informasi Program pengampunan Pajak bagi Wajib Pajak UMKM dengan mendatangi di tempat usaha UMKM, seperti di pinggir jalan, Pasar, Mall, di wilayah Kelurahan kelurahan pada Kecamatan di Kramat Jati.

3. Mengadakan program jemput bola dari pegawai pajak Kantor Pelayanan Pajak Kramat Jati, dengan mendatangani pelaku usaha UMKM dalam menjalankan Program Pengampunan Pajak, serta menerima laporan Surat Pemberitahuan Tahun (SPT) Wajib Pajak UMKM. 


\section{DAFTAR PUSTAKA}

Laporan Data Penerimaan Wajib Pajak, 2016. Kantor Pelayanan Pajak Pratama Kramat Jati

Laporan Anggaran Pendapatan Belanja Negara (APBN), 2016. Kementerian Keuangan RI

Peraturan Menteri Keuangan (PMK) Nomor: Nomor 118/PMK.03/2016 tentang Pengampunan Pajak

Resmi, Siti, Perpajakan, Salemba Empat, Jakarta 2016

Soemitro, Rohmat, dalam ( Mardiasmo) Perpajakan, Penerbit BPFE Yogyakarta 2016

Undang Undang Nomor Undang Undang No 11 Tahun 2016 tentang Pengampunan Pajak dan Prosedur. 2016. Republik Indonesia.

Undang Undang Nomor 36 Tahun 2008 tentang Pajak Penghasilan

Waluyo, Perpajakan Indonesia, Salemba Empat, Jakarta 2017

Erica, D. (2017). Prosedur Perhitungan Thd Pengampunan Pajak. E- Journal BSI, 7.

Fikriningrum, W. K. (2012). Analisis Faktor Faktor Yang Mempengaruhi WP Orang Pribadi Dalam Memenuhi Kewajiban Membayar Pajak. Jurnal Undip, 2.

Hasan. (2013). Indentifikasi Dan Klasifikasi UMK Di Sekitar Kampus Universitas Parahyangan. Journal Unpar, 2.

Huslim, N. D. (2015). Pengaruh Sunset Policy Tax Amnesty Dan Sanksi Pajak Thdp Kepatuhan WP Pada KPP Kembangan. E Jounal Tarumanagera, 232.

Ngadiman. (2015). Pengaruh Susnset Policy Tax Amnesty Dan Sanksi Pajak Thd Kepatuhan WP Pada KPP Kembangan. E Journal Tarumanegara, 233.

Pajak, T. A. (2013). Kesadaran Perpajakan Sanksi Pajak Sikap Fiskus Thd Kepatuhan WPOP Dikabupaten Minahasa Selatan. Unsrat E Journal , 2. 